\title{
Amelogenin Downregulates Interferon Gamma-Induced Major Histocompatibility Complex Class II Expression Through Suppression of Euchromatin Formation in the Class II Transactivator Promoter IV Region in Macrophages
}

OPEN ACCESS

Edited by:

Elodie Segura,

Institut Curie, France

Reviewed by:

Olivier Joffre,

Maria Sklodowska Curie Institute of

Oncology, Poland

Greta Forlani,

University of Insubria, Italy

*Correspondence:

Terukazu Sanu

sanuteru@dent.kyushu-u.ac.jp

Takao Fukuda

tfukuda@dent.kyushu-u.ac.jp

Specialty section:

This article was submitted to Antigen Presenting Cell Biology,

a section of the journal

Frontiers in Immunology

Received: 26 January 2020 Accepted: 30 March 2020

Published: 21 April 2020

Citation:

Yotsumoto K, Sanui T, Tanaka U, Yamato $H$, Alshargabi R, Shinjo T, Nakao Y, Watanabe Y, Hayashi C,

Taketomi T, Fukuda $T$ and Nishimura $F$ (2020) Amelogenin Downregulates Interferon Gamma-Induced Major Histocompatibility Complex Class II Expression Through Suppression of Euchromatin Formation in the Class II Transactivator Promoter IV Region in Macrophages.

Front. Immunol. 11:709. doi: 10.3389/fimmu.2020.00709
Karen Yotsumoto ${ }^{1}$, Terukazu Sanui ${ }^{1 *}$, Urara Tanaka ${ }^{1}$, Hiroaki Yamato ${ }^{1}$, Rehab Alshargabi ${ }^{1}$, Takanori Shinjo ${ }^{1}$, Yuki Nakao ${ }^{1}$, Yukari Watanabe ${ }^{1}$, Chikako Hayashi ${ }^{1}$, Takaharu Taketomi ${ }^{2}$, Takao Fukuda ${ }^{1 *}$ and Fusanori Nishimura ${ }^{1}$

${ }^{1}$ Division of Oral Rehabilitation, Department of Periodontology, Faculty of Dental Science, Kyushu University, Fukuoka, Japan, ${ }^{2}$ Dental and Oral Medical Center, Kurume University School of Medicine, Kurume, Fukuoka, Japan

Enamel matrix derivatives (EMDs)-based periodontal tissue regenerative therapy is known to promote healing with minimal inflammatory response after periodontal surgery, i. e., it promotes wound healing with reduced pain and swelling. It has also been reported that macrophages stimulated with amelogenin, a major component of EMD, produce various anti-inflammatory cytokines and growth factors. We previously found that stimulation of monocytes with murine recombinant M180 (rM180) amelogenin suppresses major histocompatibility complex class II (MHC II) gene expression using microarray analysis. However, the detailed molecular mechanisms for this process remain unclear. In the present study, we demonstrated that rM180 amelogenin selectively downmodulates the interferon gamma (IFN $\gamma$ )-induced cell surface expression of MHC II molecules in macrophages and this mechanism mediated by rM180 appeared to be widely conserved across species. Furthermore, rM180 accumulated in the nucleus of macrophages at $15 \mathrm{~min}$ after stimulation and inhibited the protein expression of class II transactivator (CIITA) which controls the transcription of MHC II by IFN $\gamma$. In addition, reduced MHC II expression on macrophages pretreated with rM180 impaired the expression of $\mathrm{T}$ cell activation markers CD25 and CD69, T cell proliferation ability, and $\mathrm{IL}-2$ production by allogenic CD4 ${ }^{+} \mathrm{T}$ lymphocytes in mixed lymphocyte reaction assay. The chromatin immunoprecipitation assay showed that IFN $\gamma$ stimulation increased the acetylation of histone $\mathrm{H} 3$ lysine 27, which is important for conversion to euchromatin, as well as the trimethylation of histone $\mathrm{H} 3$ lysine 4 levels in the CIITA promoter IV (p-IV) region, but both were suppressed in the group stimulated with IFN $\gamma$ after rM180 treatment. In conclusion, the present study shows that amelogenin suppresses MHC II expression by altering chromatin structure and inhibiting CIITA p-IV transcription activity, and attenuates subsequent $T$ cell activation. Clinically observed acceleration of 
wound healing after periodontal surgery by amelogenin may be partially mediated by the mechanism elucidated in this study. In addition, the use of recombinant amelogenin is safe because it is biologically derived protein. Therefore, amelogenin may also be used in future as an immunosuppressant with minimal side effects for organ transplantation or MHC II-linked autoimmune diseases such as type I diabetes, multiple sclerosis, and rheumatoid arthritis, among others.

Keywords: amelogenin, periodontal tissue regeneration, macrophages, major histocompatibility complex class II, interferon gamma, class II transactivator, immunosuppression

\section{INTRODUCTION}

Periodontitis is the leading cause of tooth loss in adults and is characterized by chronic inflammation of the periodontal tissue due to pathogenic periodontal bacterial infection. Periodontal lesions progress with slow tissue destruction, eventually leading to tooth loss $(1,2)$. Traditional periodontal interventions have only sought to prevent the progression of periodontal disease; however, there has been a strong demand in recent years for therapeutic strategies that aim to rebuild healthy periodontal tissue. Many periodontal tissue regenerative methods have thus been developed to meet this demand (3). One such treatment strategy is the use of enamel matrix derivatives (EMDs) such as Emdogain ${ }^{\circledR}$, which are now widely used in periodontal surgery. This strategy was developed based on the concept of mimicking the specific developmental environment for teeth, and has achieved positive clinical results (4-6). Emdogain ${ }^{\circledR}$ is an EMD that is extracted and purified from porcine tooth germs at the age of 6 months. Amelogenin is the most abundant protein present in Emdogain ${ }^{\circledR}$ and is central to EMD activity, apart from enamelin, ameloblastin, tuftelin, differentiation-inducing factors, and growth factors (7).

Amelogenin is an extracellular matrix (ECM) protein of size $20-25 \mathrm{kDa}$ that is secreted primarily by ameloblasts during tooth development. Amelogenin contains a hydrophobic region at the $\mathrm{N}$-terminus and a hydrophilic region at the $\mathrm{C}$ terminus, but overall, the protein's biochemical properties are dominated by the proline-rich hydrophobic region. Amelogenin is heavily secreted during enamel formation and is composed of a molecular aggregate called an amelogenin nanosphere. Hydrophobic amelogenin nanospheres in the ECM act as a scaffold for ameloblasts during the development of tooth germs, and are degraded by serine proteases and enamelysin (matrix metalloproteinase-20) upon calcification of the enamel $(8,9)$. Fragments of amelogenin nanospheres are also known to promote the growth of crystalline hydroxyapatite. Furthermore, amelogenin is thought to be involved in the formation of cementum through deposition on the dentin of the root. In fact, enamel and cementum hypoplasia has been observed in the oral cavity of amelogenin-deficient mice (10). In recent years, a number of studies have claimed that ECMs including amelogenin control cellular functions such as proliferation, survival, migration, and differentiation, and that they play an important role in regulating tissue remodeling. They are involved in homeostatic tissue anabolic and catabolic processes, rather than maintaining a stable structure during biological processes such as development and wound healing (11).

EMD-based periodontal tissue regenerative therapy is known to promote healing with minimal inflammatory response after periodontal surgery, i.e., it promotes wound healing with markedly reduced pain and swelling (12). It has also been reported that macrophages stimulated with amelogenin produce various anti-inflammatory cytokines and growth factors such as interleukin-10 (IL-10), vascular endothelial growth factor (VEGF), and insulin-like growth factor-1 (IGF-1) (13). However, most studies discussing the relationship between amelogenin and wound healing have been dominated by phenomenology, and few have provided a detailed molecular mechanism of amelogenin's role in wound healing.

In generally, periodontal inflammation involves an immune response to periodontal pathogenic bacteria initiated by the recognition and presentation of foreign antigens via macrophages, dendritic cells, or B lymphocytes. Foreign antigens induce adoptive immune responses and activate a pro-inflammatory environment that shifts the differentiation of $\mathrm{CD}^{+} \mathrm{T}$ lymphocytes toward a Th1 phenotype. These Th1 cells produce the pro-inflammatory cytokines interferon gamma (IFN $\gamma$ ) which promotes bactericidal activity, secretion of other pro-inflammatory cytokines, and tumor suppression by macrophages. In addition, IFN $\gamma$ enhances the expression of many crucial molecules on the surface of antigen-presenting cells, such as major histocompatibility complex class I (MHC I), MHC II, and costimulatory molecules CD80/86 at the transcriptional level (14-19). In particular, the transcription of MHC II by IFN $\gamma$ is controlled by transcriptional master regulator, class II transactivator (CIITA) (20-22). CIITA assembles a complex of transcription factors such as regulatory factor X (RFX), cyclic-AMP-responsive-element-binding protein (CREB), and nuclear transcription factor Y (NFY) at the MHC II gene promoters (23).

Some immunosuppressant drugs exert its immune tolerance by inhibiting the expression of MHC II molecules (24-26), and the reduced MHC II expression induces wound healing through the transformation of macrophages (27-30). We previously found that the stimulation of monocytes with murine recombinant M180 (rM180) amelogenin, a major component of EMD, suppresses MHC II gene expression using microarray analysis (31). However, the detailed molecular mechanisms for this process remain unclear. The elucidation of this mechanism contributes to gaining better insight into the resolution of 
inflammation by EMD during periodontal tissue regenerative processes, and also in understanding the potential role of amelogenin in the regulation of immunological rejection for future establishment of novel tolerogenic immunosuppressive therapy for organ transplantation. Hence, the aims of this study were to examine in detail the molecular mechanisms underlying amelogenin action on macrophages and to verify its effects on the antigen presentation of IFN $\gamma$-induced MHC II.

\section{MATERIALS AND METHODS}

\section{Cell Cultures}

The THP-1 human monocytic cell line and the RAW264.7 murine macrophage cell line were purchased from RIKEN BioResouce Center (Ibaraki, Japan). THP-1 cells were maintained in RPMI-1640 medium (Nacalai Tesque, Kyoto, Japan) containing $10 \%$ heat-inactivated fetal bovine serum (FBS), penicillin, and streptomycin at $37^{\circ} \mathrm{C}$ in a $5 \% \mathrm{CO}_{2}$ incubator. Cells were sub-cultured every $48-72 \mathrm{~h}$, inoculum being $5 \times$ $10^{5} / \mathrm{mL}$, and cell viability ( $>95 \%$ ) was confirmed by trypan blue exclusion. After the THP-1 cells were stimulated with $50 \mathrm{nM}$ phorbol-myristate-acetate (PMA) (Sigma Aldrich, St. Louis, MO, USA) for $24 \mathrm{~h}$, they were washed with phosphate-buffered saline (PBS, pH 7.4) and replaced with PMA-free RPMI-1640 medium with FBS for another $24 \mathrm{~h}$. These differentiated macrophages were pretreated with or without $10 \mu \mathrm{g} / \mathrm{mL}$ recombinant murine M180 amelogenin (rM180) for $24 \mathrm{~h}$, and then stimulated with $2.5 \mathrm{ng} / \mathrm{mL}$ recombinant human IFN $\gamma$ (PeproTech, Rocky Hill, NJ, USA) for 24,36 , and $48 \mathrm{~h}$. The murine macrophage cell line RAW264.7 (American Type Culture Collection (ATCC), Manassas, VA, USA) was maintained in Dulbecco's modified Eagle's medium (DMEM) (Nacalai Tesque) containing 10\% heat-inactivated FBS, penicillin, and streptomycin. RAW264.7 cells were stimulated in same manner as described for THP-1 cells using $2.5 \mathrm{ng} / \mathrm{mL}$ recombinant mouse IFN $\gamma$ (BioLegend, San Diego, CA, USA) and $10 \mu \mathrm{g} / \mathrm{mL} \mathrm{rM} 180$.

\section{Animals}

The female C57BL/6 mice ( 8 week-old) and BALB/c mice ( 8 week-old) were purchased from Charles River Laboratories Japan, Inc. (Yokohama, Japan). Experiments were approved by Animal Care and Use Committee of Kyushu University (Permit Number: A19-285-0).

\section{Preparation of Recombinant Murine M180 Amelogenin}

The cloning and expression of a glutathione $S$-transferase (GST) full-length M180 amelogenin fusion construct, and the purification of rM180 were previously described (32). Briefly, full-length cDNA for mouse amelogenin (M180) was cloned into the vector and transformed into competent Escherichia coli. The bacterial pellets containing recombinant GST-rM180 were purified, and on-column cleavage of rM180 from the GST portion of the fusion protein was carried out with the PreScission protease (GE Healthcare, Boston, MA, USA). Endotoxin removal from rM180 was confirmed by the Limulus amebocyte lysate assay (endotoxin level: $10 \mu \mathrm{g}$ of $\mathrm{rM} 180<0.03 \mathrm{EU}$ ).

\section{Flow Cytometry}

For flow cytometry analysis, THP-1 cells, RAW264.7 cells, and mouse bone marrow macrophages were seeded in a 6-well plate at a density of $1 \times 10^{6}$ cells/well. After stimulation with IFN $\gamma$, or IFN $\gamma$ after rM180 treatment for $24 \mathrm{~h}$, cells were detached with Accutase (Nacalai Tesque), centrifuged at $300 \mathrm{~g}$ for $5 \mathrm{~min}$, and washed with stain buffer (BD Pharmingen, San Diego, CA, USA). Cells were blocked with human TrusStain FcX (BioLegend) for $10 \mathrm{~min}$ at room temperature. To determine the surface expression of target molecules, cells were then washed and stained with PE anti-human HLA-DR (BioLegend), PE antihuman CD86 (BioLegend), Alexa Fluor 488 anti-human HLAA, B, C (BioLegend), and FITC anti-mouse I- $\mathrm{A}^{\mathrm{d}}$ (BioLegend). Isotype controls were used to confirm antibody specificity. Cells were incubated in the dark for $30 \mathrm{~min}$ at $4^{\circ} \mathrm{C}$ and analyzed using a BD FACSVerse flow cytometer (BD Biosciences, San Diego, CA, USA). Data were processed using FlowJo ${ }^{\mathrm{TM}}$ (v10.5.3) software (BD Biosciences).

\section{Confocal Microscopy Experiments}

PMA-differentiated THP-1 cells were seeded onto a glass slide, and stimulated with rM180 for 0, 2, 5, 15, $30 \mathrm{~min}, 1,12$, and $24 \mathrm{~h}$ to observe the intracellular uptake of rM180. After stimulation, cells were fixed using $4 \%$ paraformaldehyde (PFA) for $20 \mathrm{~min}$, blocked with Blocking One Histo (Nacalai Tesque) for $5 \mathrm{~min}$ at room temperature, treated with $0.5 \%$ Triton X-100 (Junsei, Tokyo, Japan), which penetrated into the cells, for $10 \mathrm{~min}$ at room temperature, and stained with primary anti-amelogenin (F-11): sc-36528 (1:250; Santa Cruz Biotechnology, Inc, Dallas, TX, USA) antibodies overnight at $4^{\circ} \mathrm{C}$. To observe the cell surface expression of MHC II molecules, cells were stained with primary anti-HLA-DR (L243): sc-18875 (1:250; Santa Cruz Biotechnology, Inc.). Subsequently, Alexa Fluor ${ }^{\circledR} 594$ goat antimouse IgG (minimal x-reactivity) (1:1000; BioLegend) was used as secondary antibody for $2 \mathrm{~h}$ in the dark at room temperature. The nucleus was stained using SlowFade ${ }^{\circledR}$ Diamond Antifade Mountant with DAPI (Life Technologies, Waltham, MA, USA). The images were analyzed by ZEISS LSM700 (Carl Zeiss, Oberkochen, Germany) and ZEN 2012 software.

\section{RNA Isolation, cDNA Synthesis, and Quantitative PCR}

Total RNA was isolated from stimulated or unstimulated macrophages using ISOGEN II (Nippon Gene, Tokyo, Japan). The RNA was quantified by NanoDrop (Thermo Fisher Scientific, Waltham, MA, USA). PrimeScript RT Master Mix (Takara Bio, Otsu, Japan) was used to generate firststrand cDNA. The gene expression level was quantified using Applied Biosystems StepOnePlus ${ }^{\text {TM }}$ Real-Time PCR System (Life Technologies, Waltham, MA, USA) according to the attached protocol using KAPA SYBR ${ }^{\circledR}$ FAST qPCR Kit (Nippon Genetics, Tokyo, Japan). PCR was performed as per following program: $95^{\circ} \mathrm{C}$ for $3 \mathrm{~min}, 40$ cycles of $95^{\circ} \mathrm{C}$ for $3 \mathrm{~s}$, and $60^{\circ} \mathrm{C}$ for $30 \mathrm{~s}$. Glyceraldehyde3-phosphate dehydrogenase (GAPDH) was used as an internal control. The relative expression levels of HLA$\mathrm{DR}$ and CIITA were calculated using the $\Delta \Delta \mathrm{Ct}$ method. 
The PCR primer sequences were as follows; 5'-GGACAAAGCCAACCTGGAAA-3' (forward)

HLA-DR, and 5 -

CIITA, AGGACGTTGGGCTCTCTCAG-3' (reverse);

$5^{\prime}$-CCGACACAGACACCATCAAC-3' (forward) CTTTTCTGCCCAACTTCTGC-3' (reverse); 5'-TCCTCAGTGCCTACACCAACTAATG-3' and 5'-CTGGATCTCACTTCCGTTCATTCTC-3' (reverse); and GAPDH, 5' $5^{\prime}$-CTTTTCTGCCCAACTTCTGC- $3^{\prime}$ (forward) and 5'-GTCATACCAGGAAATGAGC-3' (reverse).

\section{Western Blots}

$1 \times 10^{6}$ cells of THP- $1\left(3 \times 10^{6}\right.$ cells were used to detect CIITA) stimulated with $\mathrm{rM} 180$ and IFN $\gamma$ were lysed and cell extracts representing the total protein content of the cell were separated by $10 \%$ sodium dodecyl sulfate-polyacrylamide gel, and transferred to a polyvinylidene difluoride membrane $(40 \mathrm{~min}, 16 \mathrm{~V})$. Following this, the membranes were blocked with 5\% skimmed milk in Tris-buffered saline Tween (TBS-T, $20 \mathrm{mM}$ Tris- $\mathrm{HCl}$, pH 7.4, $137 \mathrm{mM} \mathrm{NaCl}$, and $0.1 \%$ Tween 20) for $30 \mathrm{~min}$. Subsequently, the membranes were incubated overnight at $4^{\circ} \mathrm{C}$ with specific antibodies: anti-CIITA $(7-1 \mathrm{H})$ : sc-13556 (1:1000, Santa Cruz Biotechnology), anti-IRF-1: 11335-1-AP (1:1000, Proteintech, Chicago, IL, USA), antiSTAT1 (1:1000, Cell Signaling Technology, Danvers, MA, USA), anti-phospho-STAT1 (1:1000, Santa Cruz Biotechnology), anti-JAK2 (D2E12) (1:1000, Cell Signaling Technology), anti-phospho-JAK2 (Tyr1007/1008) (C80C3) (1:1000, Cell Signaling Technology), and anti- $\beta$-actin (1:1000, Cell Signaling Technology). The membrane was washed five times with TBS$\mathrm{T}$ buffer and exposed to horseradish peroxidase-conjugated secondary antibody. After washing with TBS-T, the membrane was chemiluminescently detected using Chemi-Lumi One Super (Nacalai Tesque) and developed by ImageQuant LAS 4000 (GE Healthcare, Boston, MA, USA). Densitometric analysis of bands was performed using the Image J program $(\mathrm{NIH}$, Bethesda, MD, USA).

\section{Chromatin Immunoprecipitation (ChIP) Assay}

THP-1 $\left(8 \times 10^{6}\right)$ cells were seeded in a $15-\mathrm{cm}$ dish. To crosslinked chromatin, cells were fixed in $4 \%$ PFA for $10 \mathrm{~min}$. The ChIP assay was performed using the SimpleChIP ${ }^{\circledR}$ Enzymatic Chromatin IP Kit (Agarose Beads) (Cell Signaling Technology) according to the manufacturer's recommendations. To analyze histone modification, the following antibodies were used: anti- Histon $\mathrm{H} 3$ (D2B12) $\mathrm{XP}^{\circledR}$ (ChIP formulated) \#4620 for positive control, anti- normal rabbit IgG \#2729 for negative control, and anti-tri-methyl-histone H3 (Lys9) (D4W1U) (Cell Signaling Technology), anti-AbFlex ${ }^{\circledR}$ Histon H3K4me3 (Active Motif, Carlsbad, CA, USA), anti-AbFlex ${ }^{\circledR}$ Histon H3K27ac (Active Motif), anti-AbFlex ${ }^{\circledR}$ Histon H3K9me3 (Active Motif), anti-AbFlex ${ }^{\circledR}$ Histon H3K27me3 (Active Motif). Purified DNA was analyzed by quantitative real-time PCR using specific primers for CIITA promoter IV (p-IV), 5'-CAG TTGGGATGCCACTTCTGA-3' (forward) and 5'- TGGAGCAA CCAAGCACCTACT-3' (reverse); and GAPDH, 5' -TACTAGCG GTTTTACGGGCG-3' (forward) and 5' -TCGAACAGGAGGAG
CAGAGAGCGA-3'. Primers for GAPDH promoter were used as negative control. PCR reactions include the positive control histone $\mathrm{H} 3$ sample, the negative control normal rabbit IgG sample, a serial dilution of the $2 \%$ input chromatin DNA (undiluted, 1:5, 1:25, 1:125) to create a standard curve and determine the efficiency of amplification. Quantitative PCR results were analyzed using the software provided with the real-time PCR machine. The IP efficiency were manually calculated using the Percent Input Method and the equation shown below. With this method, signals obtained from each immunoprecipitation are expressed as a percent of the total input chromatin.

$$
\begin{aligned}
\text { Percent Input } & =2 \% \times 2^{(\mathrm{C}[\mathrm{T}] 2 \% \text { Input Sample-C[T] IP Sample })} \\
\mathrm{C}[\mathrm{T}]=\mathrm{C}_{\mathrm{T}} & =\text { Threshold cycle of PCR reaction }
\end{aligned}
$$

\section{Mixed Lymphocyte Reaction (MLR)}

Mouse bone marrow-derived macrophages were generated from bone marrow mononuclear cells from wild-type C57BL/6 mice. Briefly, femurs and tibiae were collected from 8 week-old mice. After removing bone-adjacent muscles, marrow cells were extracted by flushing RPMI-1640 medium through the bone interior. The cells were then suspended on RPMI-1640 medium containing $10 \%$ heat-inactivated FBS, and $40 \mathrm{ng} / \mathrm{ml}$ mouse $\mathrm{M}$ CSF (Miltenyi Biote, Bergisch Gladbach, Germany) and plated on $10 \mathrm{~cm}$-dishes. On days 3 and 5, the cells were refed. On day 8 , cells were harvested and the expression of monocyte $\left(\mathrm{F} 4 / 80^{+}, \mathrm{CD} 1 \mathrm{~b}^{+}\right)$markers was analyzed by flow cytometry using APC anti-mouse F4/80 (BioLegend) and PE anti-mouse CD11b (BioLegend). The cells were seeded in 6 -well $\left(1 \times 10^{6}\right.$ cells/well) and 96-well plates $\left(5 \times 10^{5}\right.$ cells/well). Cells were stimulated either with IFN $\gamma$, or IFN $\gamma$ after rM180 treatment. After cells were washed with PBS and stimulated with IFN $\gamma$ for another $24 \mathrm{~h}, \mathrm{CD}^{+} \mathrm{T}$ cells were added. $\mathrm{CD} 4^{+} \mathrm{T}$ cells were isolated from the spleen of $\mathrm{BALB} / \mathrm{c}$ mice by positive selection using MojoSort ${ }^{\mathrm{TM}}$ Mouse CD4 T Cell Isolation Kit (BioLegend). CD4 ${ }^{+} \mathrm{T}$ cells were co-cultured with mouse bone marrow-derived macrophages in a 1:1 ratio. Additionally, we cultured only $\mathrm{CD}^{+} \mathrm{T}$ cells as a control. After $48 \mathrm{~h}$ of coculture in 6-well plates, $\mathrm{T}$ cell activation was analyzed by flow cytometry using APC anti-mouse CD25 (BioLegend), FITC antimouse CD69 (BioLegend), and PE anti-mouse CD4 (BioLegend). For carboxyfluorescein succinimidyl ester (CFSE)-based $\mathrm{T}$ cell proliferation assay, isolated $\mathrm{CD}^{+} \mathrm{T}$ cells were labeled with CFSE using CFSE Cell Division Tracker Kit (BioLegend). T cells $\left(1 \times 10^{6}\right.$ cells $)$ were co-cultured with same number of bone marrow-derived macrophages stimulated with IFN $\gamma$ after rM180 treatment. After $48 \mathrm{~h}$, cells were stained with PE anti-mouse CD4, and then CFSE dilution was measured by flow cytometry. The IL-2 concentration in the supernatant samples was measured using Legend $\mathrm{Max}^{\mathrm{TM}}$ Mouse IL-2 ELISA Kit (BioLegend) after collecting the $72 \mathrm{~h}$-culture supernatant samples.

\section{Statistical Analysis}

The data were quantified, and the average value and its standard error (SD) were calculated. All values were expressed as mean \pm SD. Comparison between 
the groups was evaluated using One-way ANOVA or student's $t$-test. $P$-values $<0.05$ were considered statistically significant.

\section{RESULTS \\ rM180 Amelogenin Downregulated the Expression Profiles of IFN $\gamma$-Induced MHC II but Not MHC I or CD86 on Human THP-1 Cells and Murine RAW264.7 Cells}

We previously demonstrated that rM180 amelogenin suppresses IFN $\gamma$-induced MHC II gene expression in monocytic cell lines using microarray analysis (31). To clarify whether rM180 regulates IFN $\gamma$-induced $\mathrm{MHC}$ II expression in macrophages, THP-1 cells pretreated with or without rM180 for $24 \mathrm{~h}$ were stimulated with IFN $\gamma$, and then flow cytometry was used to analyze the cell surface expression of MHC II molecules. Furthermore, we distinguished cells expressing MHC II (MHC II positive cells) or not (MHC II negative cells) (Figures 1A-C). THP-1 cells strongly expressed cell surface MHC II upon stimulation with IFN $\gamma$ for 24, 36, and $48 \mathrm{~h}$ (Figures 1A-C). However, cells stimulated with IFN $\gamma$ after rM180 treatment showed an $\sim 50 \%$ reduction in the cell surface positive expression of MHC II compared with the IFN $\gamma$-only stimulation control at all time-points (right panel) although $\mathrm{rM}_{180^{+}}$ IFN $\gamma$ gradually decreased the negative expressing population in a time-dependent manner (median panel, Figures 1A-C). In contrast, cell surface expression levels of MHC I and CD86 did not differ between both groups (Figures 1D,E). The selective suppression of MHC II cell surface expression by rM180 was also validated in the mouse macrophage strain RAW264.7 cells (Figure 1F). Cell surface MHC II expression in macrophages was also visualized by immunofluorescence and confocal laser microscopy (Figure 1G). MHC II expression was seen in $80 \%$ of cells stimulated with IFN $\gamma$ only while it was almost absent in unstimulated cells, and showed $\sim 50 \%$ reduction in cells stimulated with $\mathrm{rM} 180+$ IFN $\gamma$ (Figure 1G). Quantitative real-time PCR also demonstrated that cells stimulated with $\mathrm{rM} 180+\mathrm{IFN} \gamma$ had a similar reduction in MHC II gene expression relative to cells stimulated only with IFN $\gamma$ (Figure 1H). Overall, these results demonstrated that rM180 amelogenin selectively downmodulates the IFN $\gamma$ induced cell surface expression of MHC II molecules and this mechanism mediated by rM180 appeared to be widely conserved across species.

\section{rM180 Accumulated in the Nucleus of THP-1 Macrophages}

Next, we observed the cellular uptake of rM180 amelogenin using confocal laser microscopy. rM180 showed cytoplasmic localization in macrophages at $2 \mathrm{~min}$ post-treatment, and subsequent uptake was initiated into the nucleus at $5 \mathrm{~min}$ (Figures 2A,B). rM180 accumulated in the nucleus at $15 \mathrm{~min}$ after stimulation, with the highest fluorescence intensity observed at 15-30 min (Figures 2A,B).
rM180 fluorescence was no longer observable after 12-24 h (Figure 2A).

\section{Decreased MHC II Expression on Murine Bone Marrow Macrophages by rM180 Downregulated Allogenic CD4 ${ }^{+}$T Cell Activation}

MHC II presentation by macrophages is central for priming the adaptive immune response in $\mathrm{CD}^{+} \mathrm{T}$ lymphocytes. We therefore explored the capacity of rM180 amelogeninstimulated bone marrow macrophages from C57BL/6 mice to activate allogeneic splenic $\mathrm{CD}^{+} \mathrm{T}$ cells isolated from $\mathrm{BALB} / \mathrm{c}$ mice. Bone marrow macrophages were isolated with purity more than 90\% (Figure 3A). Similar to the results depicted in Figure 1, the MHC II cell surface expression of mouse bone marrow macrophages from $\mathrm{C} 57 \mathrm{BL} / 6$ mice was also inhibited in cells stimulated with IFN $\gamma$ pretreated with rM180 compared to cells stimulated only with IFN $\gamma$ for 24 or $48 \mathrm{~h}$ (Figures 3B,C). Next, the expression of $\mathrm{T}$ cell activation markers CD25 and CD69, carboxyfluorescein succinimidyl ester (CFSE)-based $\mathrm{T}$ cell proliferation assay, and IL-2 production by $\mathrm{CD} 4^{+} \mathrm{T}$ lymphocytes were measured by mixed lymphocyte reaction (MLR) assay to assess the induction of $\mathrm{T}$ cell activation. The expression of CD25 and CD69 (Figure 3D), and T cell proliferation ability (Figures 3E,F), as well as the production of IL-2 (Figure 3G), was significantly lower in the group stimulated with IFN $\gamma$ after rM180 treatment compared with $\mathrm{T}$ cells that responded to macrophages stimulated only with IFN $\gamma$. These results clearly indicated that reduced MHC II expression on macrophages pretreated with rM180 impaired their capacity to activate allogenic $\mathrm{CD}^{+} \mathrm{T}$ cell responses.

\section{rM180 Downregulated CIITA Protein Expression in Macrophages}

As demonstrated before, we found that rM180 amelogenin migrated rapidly into the nucleus to suppress the cell surface expression of MHC II and allogeneic $\mathrm{T}$ cell activation. IFN $\gamma$ induction of MHC II gene expression is known to involve a process that starts with IFN $\gamma$ receptor binding, JAK/STAT phosphorylation, IFN regulatory factor-1 (IRF-1) activation, and STAT/IRF-1 binding to the promoter IV (pIV) region of CIITA. STAT/IRF-1 is a transcription activator for CIITA that initiates MHC II transcription, which in turn activates MHC II translation. To identify the signaling points that rM180 influences in this pathway, western blotting was performed. rM180 did not affect the phosphorylation of JAK or STAT1 downstream of IFN $\gamma$ receptor signaling or IRF-1 activation (Figures 4A-C). However, rM180 markedly suppressed CIITA protein expression at $24 \mathrm{~h}$ after stimulation with IFN $\gamma$ (Figure 4D). In addition, quantitative real-time PCR demonstrated that $\mathrm{rM} 180$ did not affect IFN $\gamma$ receptor gene expression on macrophages (Figure 4E). These results clearly indicated that rM180 amelogenin inhibits CIITA protein expression and consequently downregulates MHC II expression, as shown in Figure 1. 

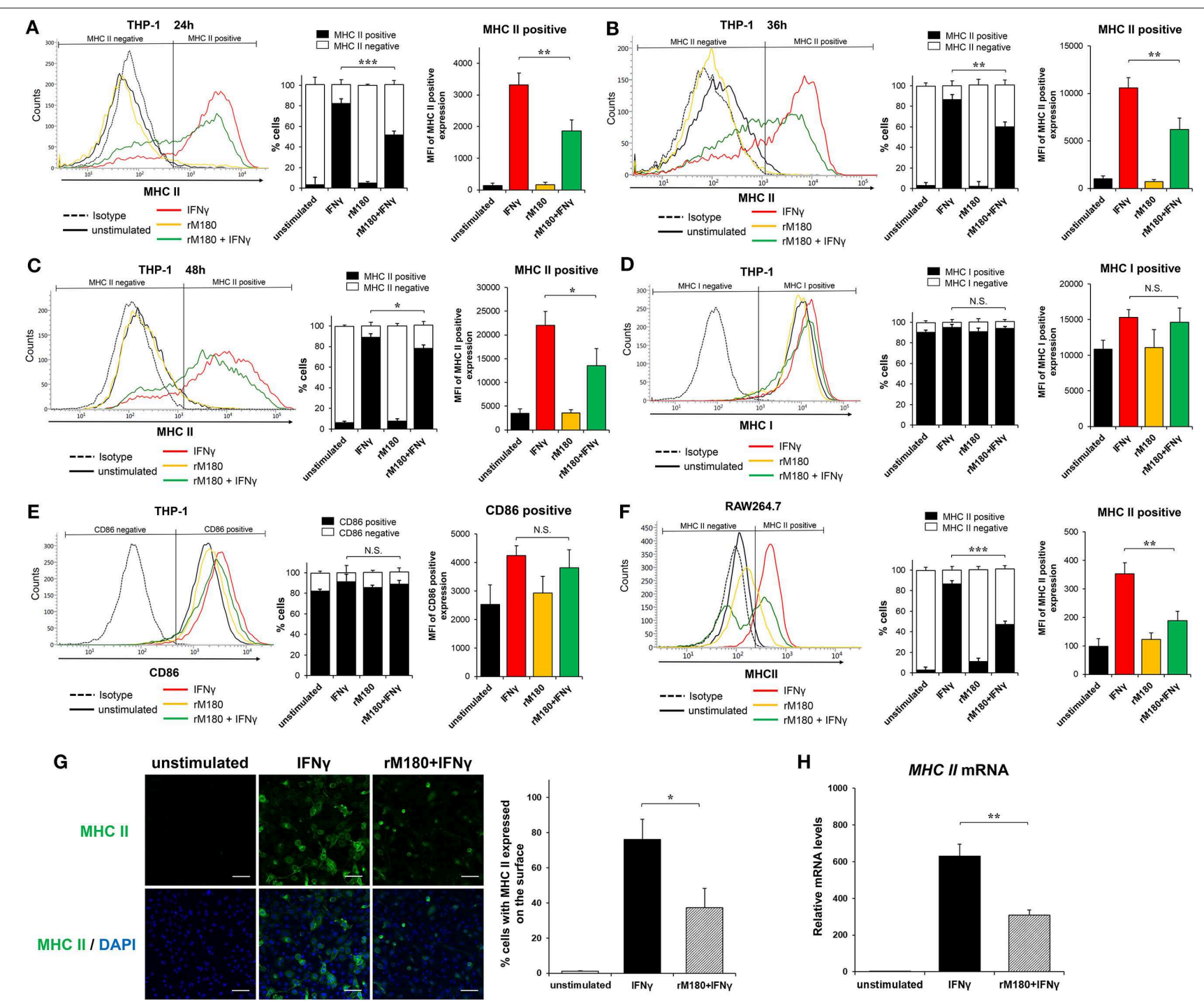

FIGURE 1 | rM180 amelogenin inhibits IFN $\gamma$-induced expression of MHC || molecules on human THP-1 macrophages and mouse RAW264.7 cells. (A-E) Human THP-1 cells were incubated with $\mathrm{rM} 180(10 \mu \mathrm{g} / \mathrm{mL})$ for $24 \mathrm{~h}$, washed, and stimulated with IFN $\gamma(2.5 \mathrm{hg} / \mathrm{mL})$ for $24 \mathrm{~h}$ (A,D,E), $36 \mathrm{~h}$ (B), and $48 \mathrm{~h}$ (C). MHC II (A-C), MHC I (D), and CD86 (E) surface expression (left) was evaluated by flow cytometry. Representative histograms are shown in left panel. (A-C) Quantification of cells expressing MHC II (MHC II positive cells) or not (MHC II negative cells) is shown in median panel. Quantification of histograms is shown in right panel. Bar graphs represent the mean fluorescence intensity (MFI) of MHC II positive expression. (F) Murine RAW264.7 cells were incubated with rM180 for $24 \mathrm{~h}$, washed, and stimulated with IFN $\gamma$ for $24 \mathrm{~h}$. MHC II surface expression was evaluated by flow cytometry. (G) The cells were fixed and stained with the anti-human MHC II antibody, followed by an Alexa 488 secondary antibody (green). Nuclei were stained with DAPI dye (blue). All confocal images are representatives of experiments conducted in triplicates. Quantification of MHC II surface expression (right). Data are expressed as percentage of cells with MHC II on the cell surface. The number of cells per experimental group was 300. Scale bars: $100 \mu \mathrm{m}$. (H) Total RNA was isolated and analyzed for MHC II mRNA expression by quantitative real-time PCR. Data are represented as fold increase in expression relative to GAPDH. N.S., not significant. The significance of differences between groups was determined by one-way ANOVAVTukey's test: ${ }^{\star} P<0.05 ;{ }^{\star \star} P<0.01 ;{ }^{\star \star \star} P<0.001$ vs. IFN $\gamma$. Data represent mean \pm SD. Similar results were obtained in six independent experiments.

\section{rM180 Appeared to Inhibit CIITA}

\section{Transcription by Suppressing Euchromatin in Macrophages}

rM180 amelogenin suppressed CIITA gene expression (Figure 5A). Therefore, we hypothesized that rM180 affects transcriptional regulation at the CIITA p-IV region and focuses on histone modification. Histone modification involves alterations to chromatin structure as well as transcription and gene regulation (33). DNA wraps around four core histones to form a nucleosome within the chromatin structure. A low degree of condensation in chromatin is called euchromatin, where histones undergo active acetylation and methylation, leading to loose DNA winding, RNA polymerase binding, and transcription initiation. Conversely, the most condensed DNA is referred to as heterochromatin, where a characteristic methyl modification tightly packs nucleosomes together, immobilizing DNA and 


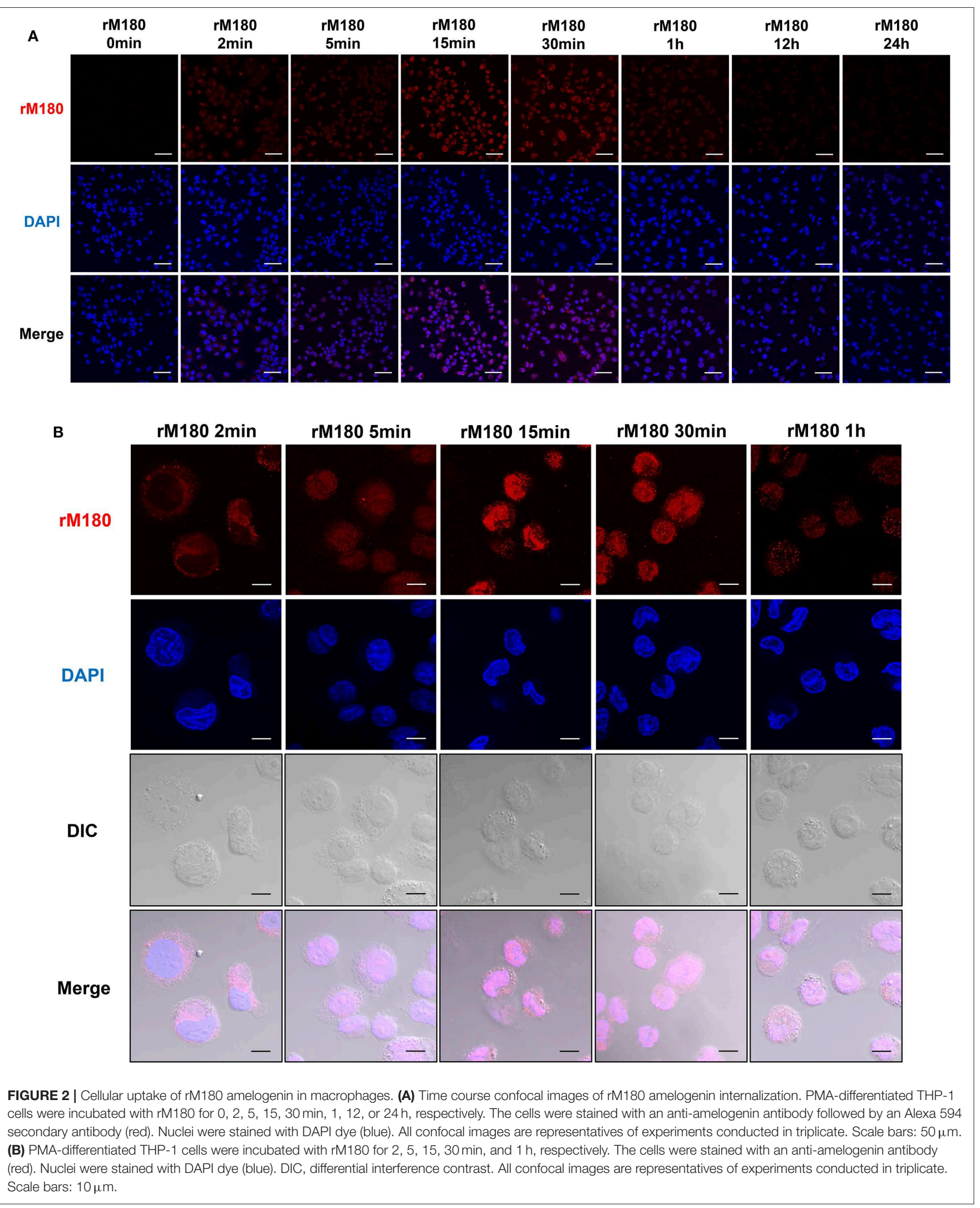




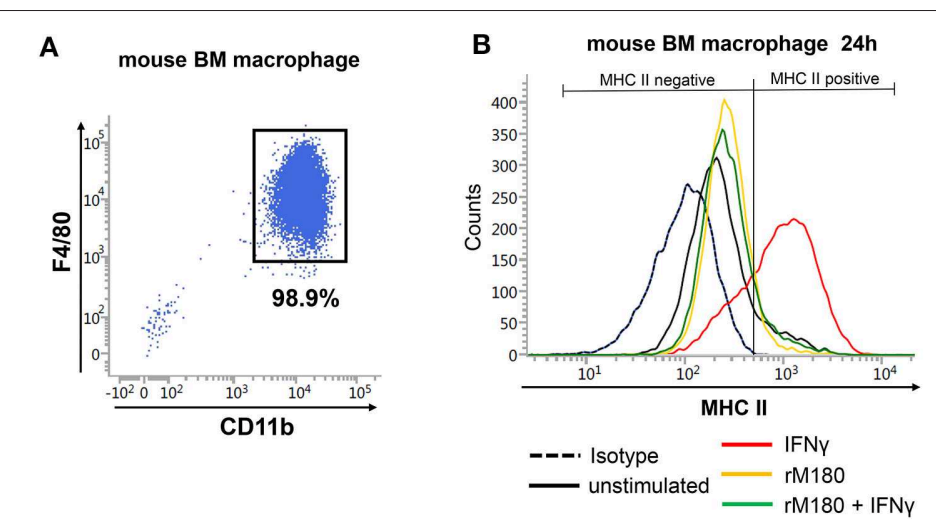

C
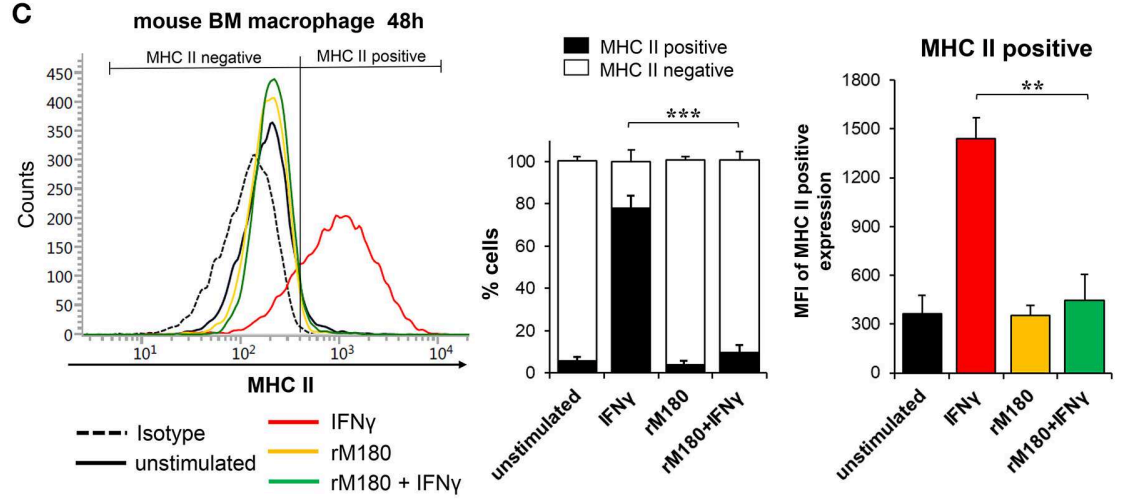

E
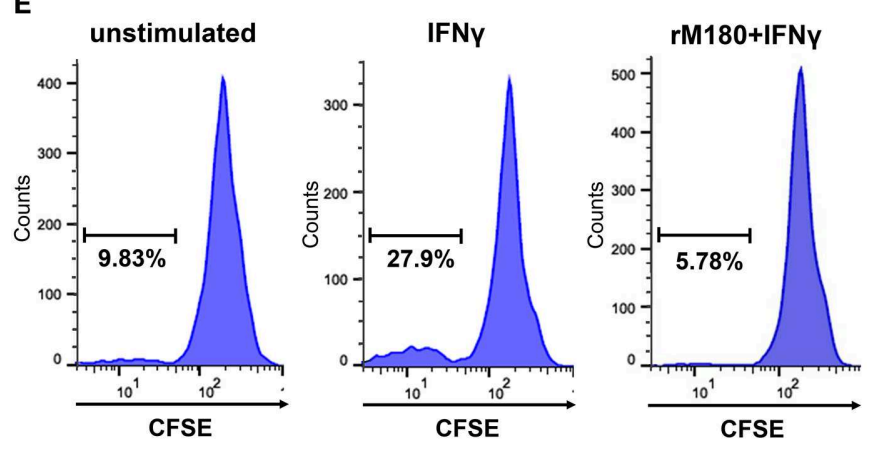
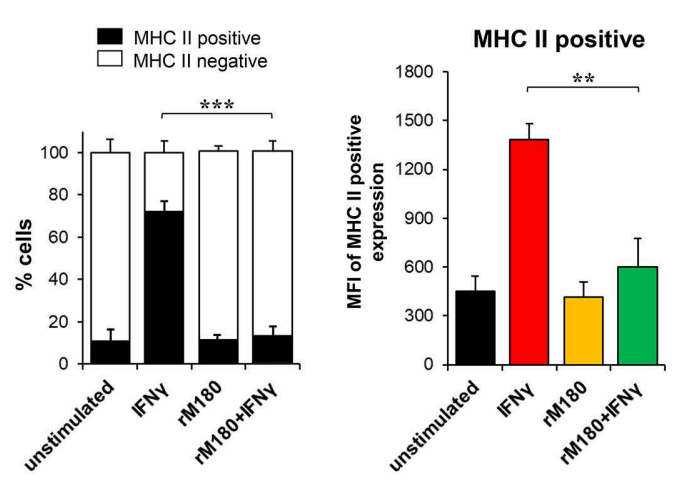

D
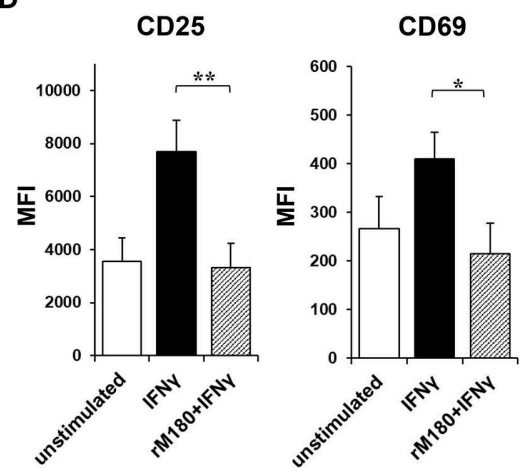

G

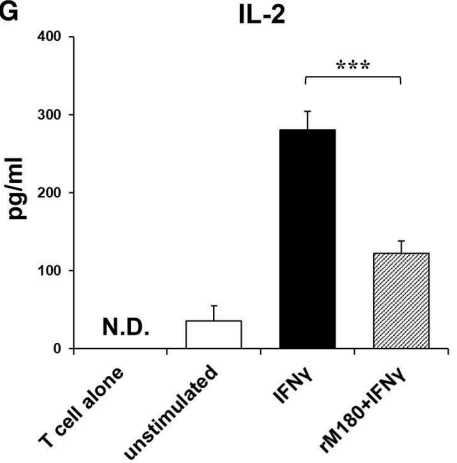

FIGURE 3 | Activation of allogeneic CD4 ${ }^{+}$T lymphocytes by rM180-pretreated bone marrow macrophages. (A) Purity of bone marrow macrophages isolated from C57BL/6 mice. Bone marrow macrophages were incubated with rM180 for $24 \mathrm{~h}$, washed, and stimulated with IFN $\gamma$ for $24 \mathrm{~h}$ (B), and $48 \mathrm{~h}$ (C). (B,C) MHC II surface expression of mouse bone marrow macrophages was evaluated by flow cytometry. Representative histograms are shown in left panel. Quantification of cells expressing MHC II (MHC II positive cells) or not (MHC II negative cells) is shown in median panel. Quantification of histograms is shown in right panel. Bar graphs represent the mean fluorescence intensity (MFI) of MHC II positive expression. (D-G) Activation of allogeneic CD4+ $T$ cells (BALB/c mice, $\mathrm{H2}$-D ${ }^{d}$ ) in a mixed leukocyte reaction (MLR; bone marrow macrophage to T cell ratio of 1:1) with or without rM180-incubated bone marrow macrophages (C57BL/6 mice, H2-D ${ }^{b}$ ). (D) CD25 and CD69 mean fluorescence intensity (MFI) in CD4 ${ }^{+} \mathrm{T}$ cells was analyzed by flow cytometry. (E,F) CD4 ${ }^{+} \mathrm{T}$ cells were labeled CFSE, and then co-cultured with bone marrow macrophages. After $48 \mathrm{~h}$, the proliferation of CD4 positive-gated cells was assessed by flow cytometry analysis of CFSE dilution. Histograms show representative data (E). Bar graphs represent the percentage of divided T cells (F). (G) IL-2 production by CD4+ T cells cocultured with rM180-incubated bone marrow macrophages was analyzed in culture supernatants at 72 h. N.D., not detected. The significance of differences between groups was determined by one-way ANOVA/Tukey's test: ${ }^{\star} P<0.05 ;{ }^{\star \star} P<0.01 ;{ }^{\star \star \star} P<0.001 \mathrm{vs}$. IFN $\gamma$. Data represent means $\pm \mathrm{SD}$. Similar results were obtained in three independent experiments.

inhibiting transcription. We therefore focused on the acetylation of histone $\mathrm{H} 3$ lysine 27 ( $\mathrm{H} 3 \mathrm{~K} 27 \mathrm{ac})$, which is important for conversion to euchromatin, as well as the trimethylation of histone $\mathrm{H} 3$ lysine 4 (H3K4me3) (34). In addition, we examined the trimethylation of $\mathrm{H} 3$ lysine $9(\mathrm{H} 3 \mathrm{~K} 9 \mathrm{me} 3)$ and $\mathrm{H} 3$ lysine 27 (H3K27me3), which is important for conversion to heterochromatin $(35,36)$. The chromatin immunoprecipitation (ChIP) assay showed that IFN $\gamma$ stimulation increased H3K27ac and H3K4me3 levels in the CIITA p-IV region, but both were suppressed in the group stimulated with IFN $\gamma$ after rM180 treatment (Figures 5B-D). On the other hand, H3K9me3 and H3K27me3 remained unaffected (Figures 5E,F). Moreover, to 
A

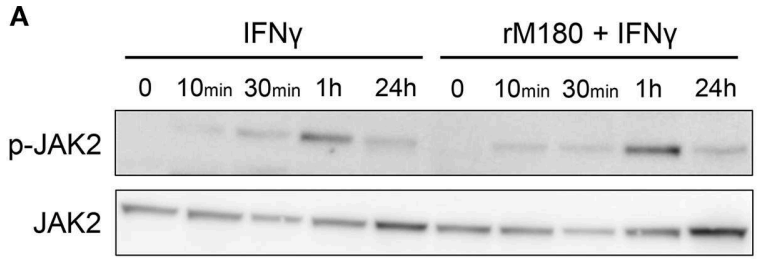

B

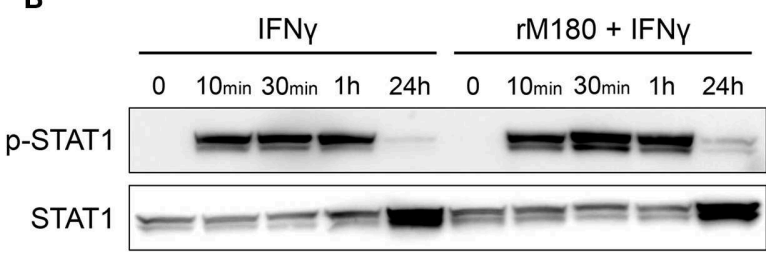

C
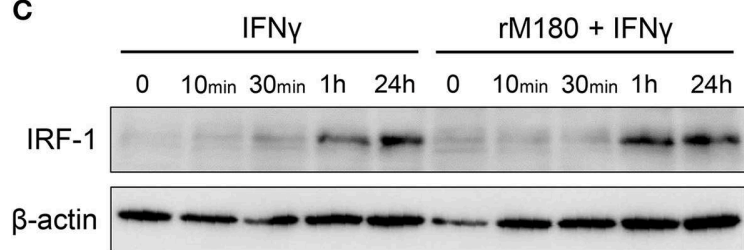

D

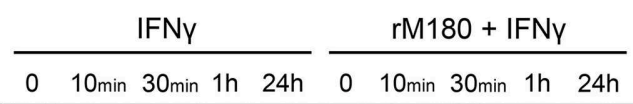

CIITA

$\beta$-actin

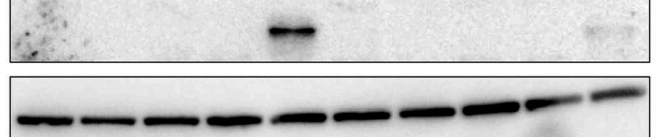

E

IFNGR1 mRNA

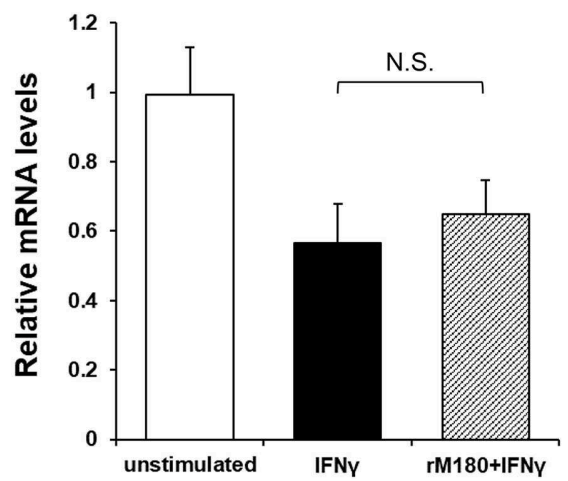

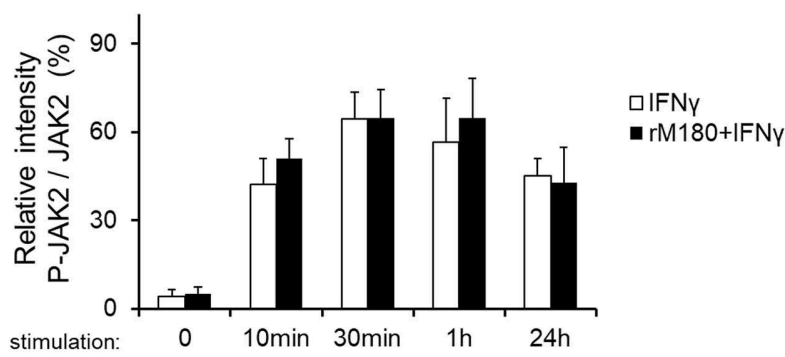

stimulation:

DIFNy

- rM180+IFNy
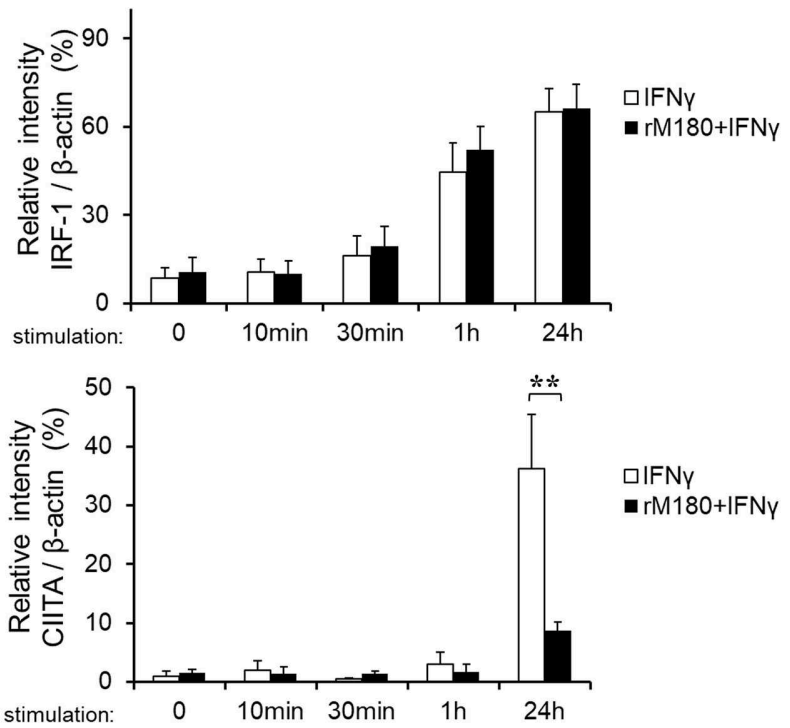

口IFNy

- rM180+IFNY

stimulation:

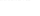

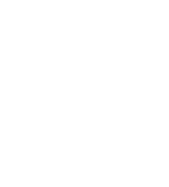


FIGURE 4 | $\beta$-actin was used as a control. Protein expression was quantified using the ImageJ program. Representative western blots of phosphorylated (A) JAK2 and (B) STAT1, and total (C) IFN regulatory factor-1 (IRF-1) and (D) class II transactivator (CIITA). Quantification of phosphorylated protein levels relative to total protein and total IRF-1 and CIITA protein levels relative to $\beta$-actin was carried out using ImageJ. The significance of differences between groups was determined by a two-tailed unpaired Student's test; ${ }^{*} P<0.01$. (E) Total RNA was isolated and analyzed for IFN $\gamma$ receptor 1 (IFNGR1) mRNA expression by quantitative real-time PCR. Data are represented as fold increase in expression relative to GAPDH. The significance of differences between groups was determined by one-way ANOVA/Tukey's test. Data represent mean \pm SD. Similar results were obtained in three independent experiments.

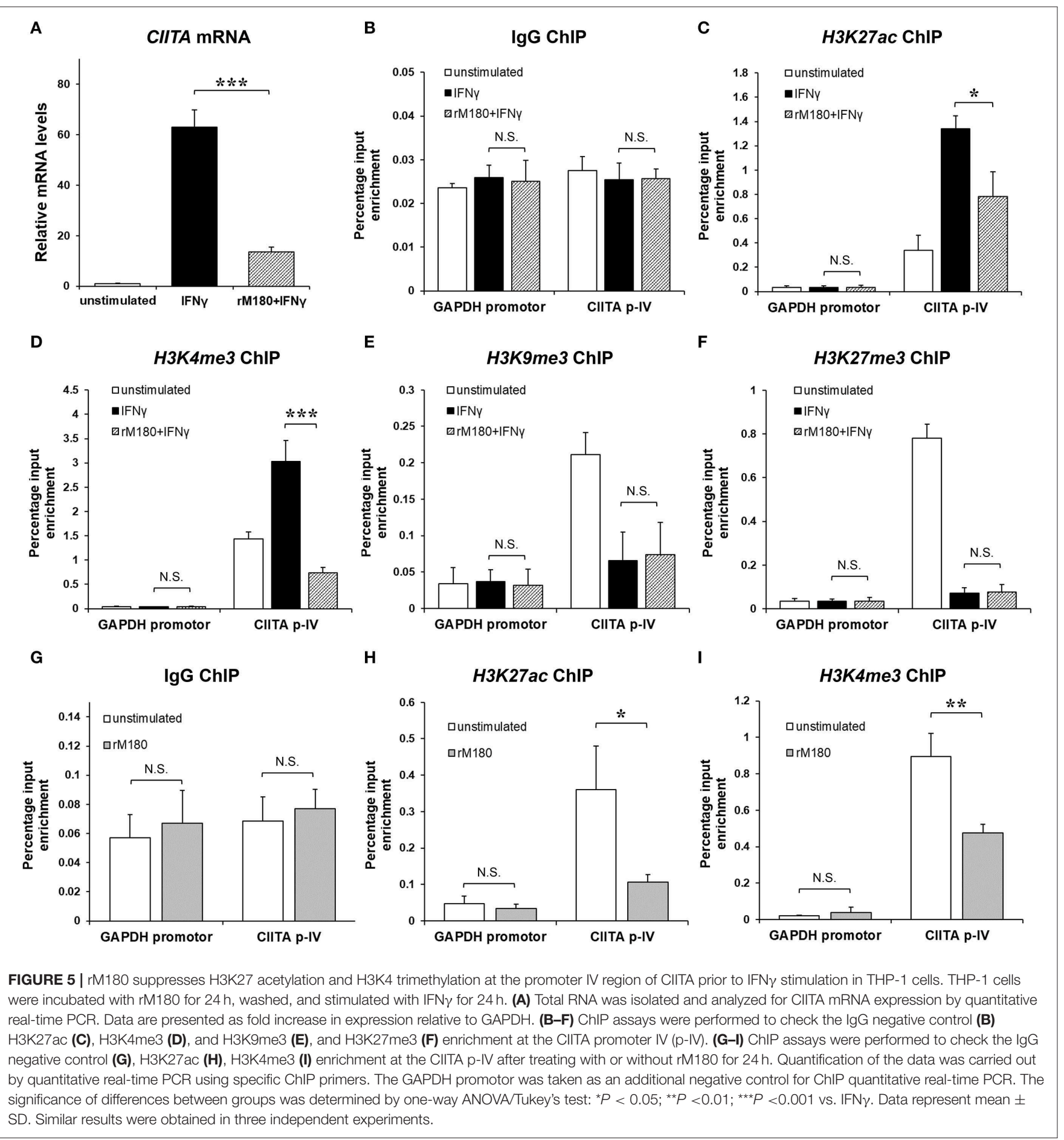




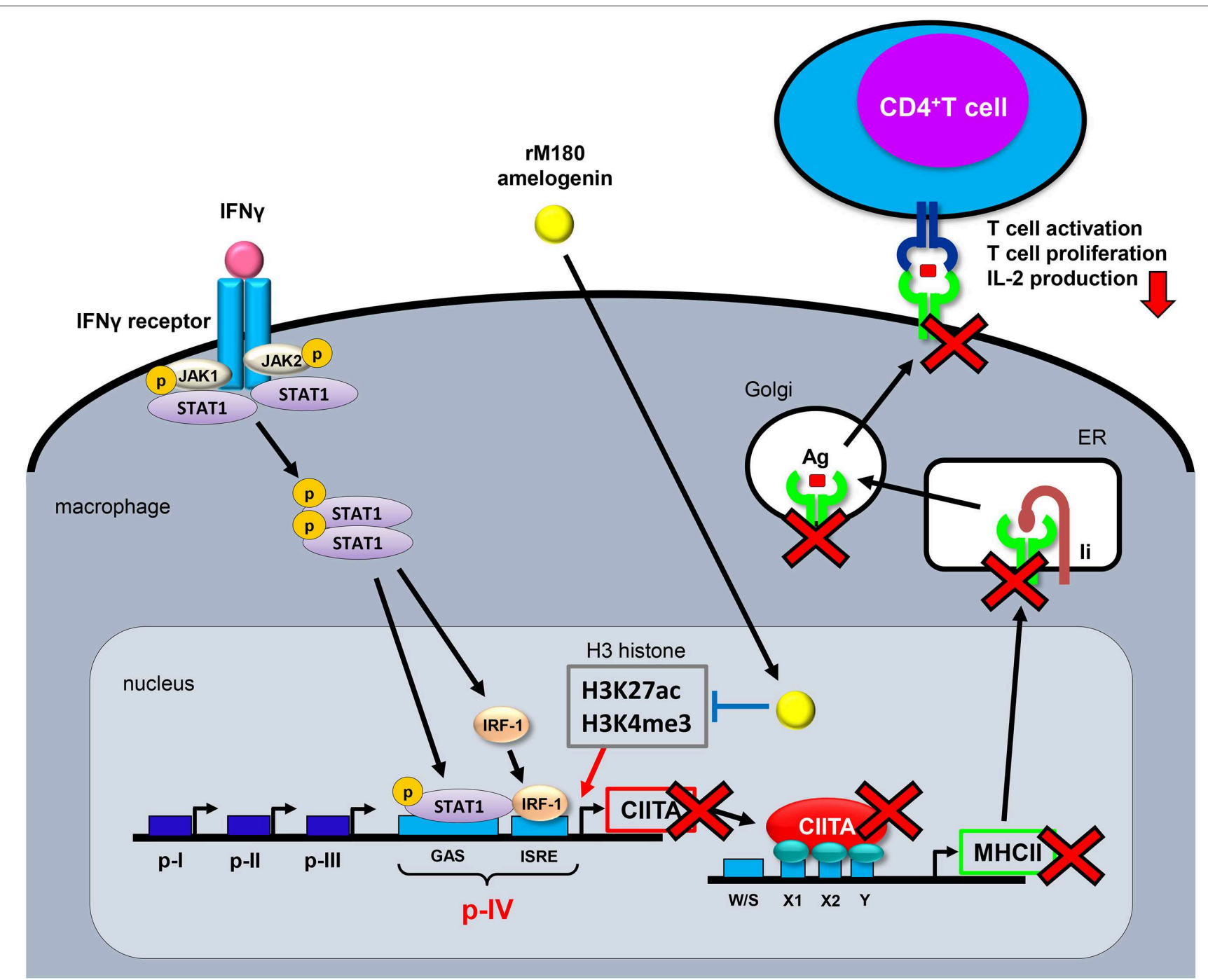

FIGURE 6 | Proposed model for the MHC II inhibition mechanism by rM180 amelogenin in macrophages. Upon IFN $\gamma$ binding to its receptor and inducing the JAK/STAT signaling pathways, the JAK/STAT is phosphorylated, IRF-1 is activated, and STAT/IRF-1 binds to the p-IV region of CIITA. STAT/IRF-1 is a transcription activator for CIITA that initiates MHC II transcription. rM180 amelogenin migrates early into macrophage nuclei to inhibit IFN $\gamma$-induced CIITA transcription through the suppression of $\mathrm{H} 3 \mathrm{~K} 27 \mathrm{ac}$ and $\mathrm{H} 3 \mathrm{~K} 4 \mathrm{me} 3$ on histone $\mathrm{H} 3$ within the CIITA $\mathrm{p}$-IV region, thereby decreasing MHC II gene transcription. This causes a reduction in the cell surface expression of MHC II molecules, which results in the attenuation of CD4+ T cell activity. li, invariant chain; ER, endoplasmic reticulum; Ag, antigen; IRF-1, IFN regulatory factor-1; CIITA, class II transactivator; GAS, IFN- $\gamma$ activated sequence; IRSE, IFN-stimulated response elements.

determine whether rM180 modulates the epigenome prior to IFN $\gamma$ stimulation, the ChIP experiments on macrophages that have only been exposed to rM180 for $24 \mathrm{~h}$ were performed. rM180 significantly suppressed H3K27ac and H3K4me3 levels in the CIITA p-IV region compared to the unstimulated group (Figures 5G-I). These results demonstrated that chromatin structural remodeling by $\mathrm{rM} 180$ amelogenin inhibits the formation of euchromatin and subsequent CIITA transcription prior to IFN $\gamma$ stimulation.

\section{DISCUSSION}

In the present study, we reported that rM180 amelogenin migrates rapidly into macrophage nuclei to selectively inhibit
MHC II cell surface expression and attenuate $\mathrm{T}$ cell activation by suppressing histone $\mathrm{H} 3$ acetylation of lysine 27 and trimethylation of lysine 4 , both of which are crucial for CIITA transcriptional activation in the promoter IV region of CIITA (Figure 6). This mechanism mediated by amelogenin appeared to be widely conserved across species.

In general, adequate control of inflammation is essential for the initiation of tissue regeneration, and macrophages play an important role both during the onset of inflammation, such as in periodontitis, as well as in wound healing after treatment. Macrophages can be broadly divided into two groups, and are classified as inflammation-mediating M1 cells or woundhealing M2 cells. M1 macrophages can be stimulated by IFN $\gamma$ alone, or synergistically by IFN $\gamma$ with other cytokines 
or bacterial components such as lipopolysaccharide (LPS). Activated M1 macrophages enhance MHC II expression and produce inflammatory factors such as inducible nitric oxide synthase (iNOS), tumor necrosis factor-alpha (TNF- $\alpha$ ), IL- $1 \beta$, and IL-6 $(37,38)$. M1 macrophages thus play a role in inducing Th1 response and supporting biological defense mechanisms directed against intracellular parasitic pathogens or tumors $(39,40)$. In contrast, M2 macrophages are induced by IL-4 and IL-13 and produce anti-inflammatory cytokines such as IL-10, transforming growth factor-beta (TGF- $\beta$ ), and VEGF. Therefore, M2 macrophages play a central role in angiogenesis, scavenging, resolution of inflammation, and transition to tissue repair (41-44). As such, macrophages are involved in both the destruction and regeneration of tissues, and play an important role within the interface of inflammation and tissue regeneration. In previous studies, we reported that timedependent expression of the M2 markers CD163 and CD206 was upregulated when macrophages were stimulated with rM180 amelogenin, and that cell morphology was changed to a spindle shape, promoting differentiation into M2 macrophages (45). Additionally, inflammatory gene expression such as TNF- $\alpha$, IL6 induced by LPS was rapidly induced at $4 \mathrm{~h}$ post-stimulation, and returned to baseline at $24 \mathrm{~h}$ in the amelogenin pretreatment group, while in macrophages stimulated with LPS alone, such gene expression prolonged up to $96 \mathrm{~h}$. In the amelogenin pretreatment group, the expression of anti-inflammatory genes, on the contrary, increased at $8 \mathrm{~h}$ post-LPS stimulation (46). Thus, amelogenin contributes to early resolution of inflammation and promotes wound healing by temporarily enhancing the initial macrophage inflammatory response and reducing the duration of inflammation.

In the present study, we found that rM180 amelogenin underwent translocation to the nucleus within $5 \mathrm{~min}$, inhibiting the transcriptional activity of CIITA via $\mathrm{H} 3 \mathrm{~K} 27 \mathrm{ac}$ and $\mathrm{H} 3 \mathrm{~K} 4 \mathrm{me} 3$ on histone $\mathrm{H} 3$ within the CIITA p-IV region (Figure 6). This is a novel finding, with no other prior studies having described amelogenin translocation to the nucleus and alterations in chromatin structure. While there have been numerous studies conducted regarding amelogenin-induced cellular function (4749), the molecules that bind to amelogenin at the cell membrane and the signaling pathways that are activated to affect cellular function remain unclear. Therefore, various studies have been conducted to identify amelogenin's binding partners. Molecules currently known to associate with amelogenin include lysosomeassociated membrane glycoprotein 1 (LAMP-1), CD63 antigens, annexin A2, sialic acid-binding Ig-like lectins (Siglec-10), cytoskeletal proteins (actin, vimentin, tubulin), nuclear proteins, etc (50-56). Following this line of inquiry, we also conducted a screen for amelogenin-binding molecules, and successfully identified glucose-regulated protein 78 (GRP78) as a binding partner (32). GRP78 is a molecular chaperone that belongs primarily to the family of vesicular heat shock proteins, but functionally has also been noted to act as a receptor. We previously found that rM180 amelogenin associates with GRP78 following rM180 treatment, and that the formation of this complex leads to early uptake into the cytoplasm and import into the nucleus (32). Furthermore, we found that when GRP78 was strongly expressed, the migration activity of periodontal ligament cells was strongly promoted by rM180 stimulation (57). A possible mechanism for this sequence of events involves the amelogenin-GRP78 complex facilitating the Rho family of GTPases, Rac1 activation to promote lamellipodia formation and providing a driving force for cell migration (57). Other studies also demonstrated that GRP78 inhibits $\mathrm{T}$ cell proliferation by suppressing MHC II expression on dendritic cells, and concluded that GRP78 in antigen-presenting cells is an immune regulatory molecule that assists in the resolution of inflammation (58). Taken together, it is possible that amelogenin is transported into the nucleus together with molecular chaperone GRP78, thereby inhibiting euchromatin formation in the CIITA p-IV region, leading to the suppression of MHC II expression.

While full-length amelogenin was used for the present study, amelogenin is also known to include over 14 isoforms that result from splice variants of precursor mRNA. Classic alternative splice variants such as leucine-rich amelogenin peptide (LRAP) and tyrosine-rich amelogenin peptide (TRAP) are known to induce different cellular functions, and significant attention has been given to their biological significance and roles (59, 60). Although the inhibition of antigen presentation functions by LRAP and TRAP should be investigated further, it seems certain that full-length amelogenin promotes wound healing by macrophages. In the field of general regenerative medicine, the ECM has been applied for the purpose of accelerated wound healing and regeneration, and, in particular, the EMD containing amelogenin as the main component has been used to treat refractory pressure ulcers under the trade name Xelma ${ }^{\circledR}$ (61). Thus, such clinically observed acceleration of wound healing for hard-to-heal ulceration by amelogenin may be partially mediated by the mechanism elucidated in this study. Since amelogenin exhibits tolerogenic immunosuppression, it can also be used as a preventive medication against immunological rejection during organ transplantation in future applications.

In conclusion, the present study shows that amelogenin suppresses MHC II expression by altering chromatin structure and inhibiting CIITA p-IV transcription activity, and attenuates subsequent T cell activation. Amelogenin is being used clinically in periodontal tissue regeneration therapy and its effectiveness has been proved; in addition, the use of recombinant protein is safe because it is biologically derived protein. Therefore, it may also be used in future as an immunosuppressant with minimal side effects for organ transplantation or MHC II-linked autoimmune diseases such as type I diabetes, multiple sclerosis, and rheumatoid arthritis, among others.

\section{DATA AVAILABILITY STATEMENT}

All datasets generated for this study are included in the article/supplementary material.

\section{ETHICS STATEMENT}

The animal study was reviewed and approved by Animal Care and Use Committee of Kyushu University. 


\section{AUTHOR CONTRIBUTIONS}

The experiments were designed and conceived by TSa, UT, TF, and FN. The experiments were performed by KY, HY, RA, TSi, YN, YW, and CH. Data was analyzed by KY, TSa, UT, TF, and FN. Materials, reagents were facilitated by TT. All experiments were supervised by FN. KY, TSa, and FN wrote the manuscript. All authors read and approved the final manuscript.

\section{REFERENCES}

1. Brown LJ, Löe H. Prevalence, extent, severity and progression of periodontal disease. Periodontol 2000. (1993) 2:5771. doi: 10.1111/j.1600-0757.1993.tb00220.x

2. Pihlstrom BL, Michalowicz BS, Johnson NW. Periodontal diseases. Lancet. (2005) 366:1809-20. doi: 10.1016/S0140-6736(05)67728-8

3. Ramseier CA, Rasperini G, Batia S, Giannobile WV. Advanced reconstructive technologies for periodontal tissue repair. Periodontol 2000. (2012) 59:185202. doi: 10.1111/j.1600-0757.2011.00432.x

4. Gestrelius S, Lyngstadaas SP, Hammarström L. Emdogain-periodontal regeneration based on biomimicry. Clin Oral Investig. (2000) 4:12025. doi: 10.1007/s007840050127

5. Hammarström L. Enamel matrix, cementum development and regeneration. $J$ Clin Periodontol. (1997) 24:658-68. doi: 10.1111/j.1600-051X.1997.tb00247.x

6. Sculean A, Kiss A, Miliauskaite A, Schwarz F, Arweiler NB, Hannig M. Tenyear results following treatment of intra-bony defects with enamel matrix proteins and guided tissue regeneration. J Clin Periodontol. (2008) 35:81724. doi: 10.1111/j.1600-051X.2008.01295.x

7. Chen E, Piddington R, Decker S, Park J, Yuan ZA, Abrams WR, et al. Regulation of amelogenin gene expression during tooth development. Dev Dyn. (1994) 199:189-98. doi: 10.1002/aja.1001990304

8. Yamakoshi Y. Porcine amelogenin: alternative splicing, proteolytic processing, protein-protein interactions, and possible functions. J Oral Biosci. (2011) 53:275-83. doi: 10.1016/S1349-0079(11)80011-3

9. Du C, Falini G, Fermani S, Abbott C, Moradian-Oldak J. Supramolecular assembly of amelogenin nanospheres into birefringent microribbons. Science. (2005) 307:1450-4. doi: 10.1126/science.1105675

10. Hatakeyama J, Sreenath T, Hatakeyama Y, Thyagarajan T, Shum L, Gibson $\mathrm{CW}$, et al. The receptor activator of nuclear factor-kappa B ligand-mediated osteoclastogenic pathway is elevated in amelogenin-null mice. J Biol Chem. (2003) 278:35743-8. doi: 10.1074/jbc.M306284200

11. Daley WP, Peters SB, Larsen M. Extracellular matrix dynamics in development and regenerative medicine. J Cell Sci. (2008) 121:25564. doi: 10.1242/jcs.006064

12. Jepsen S, Heinz B, Jepsen K, Arjomand M, Hoffmann T, Richter S, et al. A randomized clinical trial comparing enamel matrix derivative and membrane treatment of buccal Class II furcation involvement in mandibular molars. Part I: Study design and results for primary outcomes. J Periodontol. (2004) 75:1150-60. doi: 10.1902/jop.2004.75.8.1150

13. Almqvist S, Werthén M, Lyngstadaas SP, Gretzer C, Thomsen P. Amelogenins modulate cytokine expression in LPS-challenged cultured human macrophages. Cytokine. (2012) 58:274-9. doi: 10.1016/j.cyto.2012.02.001

14. Cooper AM, Dalton DK, Stewart TA, Griffin JP, Russell DG, Orme IM. Disseminated tuberculosis in interferon gamma gene-disrupted mice. J Exp Med. (1993) 178:2243-7. doi: 10.1084/jem.178.6.2243

15. Flynn JL, Chan J. Immunology of tuberculosis. Annu Rev Immunol. (2001) 19:93-129. doi: 10.1146/annurev.immunol.19.1.93

16. Flynn JL, Chan J, Triebold KJ, Dalton DK, Stewart TA, Bloom BR. An essential role for interferon gamma in resistance to Mycobacterium tuberculosis infection. J Exp Med. (1993) 178:2249-54. doi: 10.1084/jem.178.6.2249

17. Schneeberger EE, DeFerrari M, Skoskiewicz MJ, Russell PS, Colvin RB. Induction of MHC-determined antigens in the lung by interferon-gamma. Lab Invest. (1986) 55:138-44.

\section{FUNDING}

This work was supported by Grants-in-Aid for Scientific Research C (JP17K11986 and JP20K09958) from the Japan Society for the Promotion of Science, Takeda Science Foundation. Technical support was provided from the Research Support Center, Graduate School of Medical Sciences, Kyushu University.

18. Kobayashi KS, van den Elsen PJ. NLRC5: a key regulator of MHC class I-dependent immune responses. Nat Rev Immunol. (2012) 12:81320. doi: $10.1038 /$ nri3339

19. Fleischer J, Soeth E, Reiling N, Grage-Griebenow E, Flad HD, Ernst M. Differential expression and function of CD80 (B7-1) and CD86 (B72) on human peripheral blood monocytes. Immunology. (1996) 89:5928. doi: 10.1046/j.1365-2567.1996.d01-785.x

20. Accolla RS, Jotterand-Bellomo M, Scarpellino L, Maffei A, Carra G, Guardiola J. Air-1, a newly found locus on mouse chromosome 16 encoding a transacting activator factor for MHC class II gene expression. J Exp Med. (1986) 164:369-74. doi: 10.1084/jem.164.1.369

21. Steimle V, Otten LA, Zufferey M, Mach B. Complementation cloning of an MHC class II transactivator mutated in hereditary MHC class II deficiency (or gare lymphocyte syndrome). Cell. (1993) 75:13546. doi: 10.1016/S0092-8674(05)80090-X

22. Masternak K, Muhlethaler-Mottet A, Villard J, Zufferey M, Steimie V, Reith W. CIITA is a transcriptional coactivator that is recruited to MHC class II promoters by multiple synergistic interactions with an enhanceosome complex. Genes Dev. (2000) 14:1156-66. doi: 10.1101/gad.14.9.1156

23. Reith W, LeibundGut-Landmann S, Waidburger JM. Regulation of MHC class II gene expression by the class II transactivator. Nat Rev Immunol. (2005) 5:793-806. doi: 10.1038/nri1708

24. Glomsda BA, Blaheta RA, Hailer NP. Inhibition of monocyte/endothelial cell interactions and monocyte adhesion molecule expression by the immunosuppressant mycophenolate mofetil. Spinal Cord. (2003) 41:6109. doi: 10.1038/sj.sc.3101512

25. Kwiek B, Peng WM, Allam JP, Langner A, Bieber T, Novak N. Tacrolimus and TGF-beta act synergistically on the generation of Langerhans cells. J Allergy Clin Immunol. (2008) 122:126-32. doi: 10.1016/j.jaci.2008.05.005

26. Panjwani N, Akbari O, Garcia S, Brazil M, Stockinger B. The HSC73 molecular chaperone: involvement in MHC class II antigen presentation. J Immunol. (1999) 163:1936-42.

27. Chávez-Galán L, Olleros ML, Vesin D, Garcia I. Much more than M1 and $\mathrm{M} 2$ macrophages, there are also $\mathrm{CD}_{169}{ }^{+}$and $\mathrm{TCR}^{+}$macrophages. Front Immunol. (2015) 6:263. doi: 10.3389/fimmu.2015.00263

28. Spiller KL, Anfang RR, Spiller KJ, Ng J, Nakazawa KR, Daulton JW, et al. The role of macrophage phenotype in vascularization of tissue engineering scaffolds. Biomaterials. (2014) 35:447788. doi: 10.1016/j.biomaterials.2014.02.012

29. Chang YC, Chen TC, Lee CT, Yang CY, Wang HW, Wang CC, et al. Epigenetic control of MHC class II expression in tumor-associated macrophages by decoy receptor 3. Blood. (2008) 111:5054-63. doi: 10.1182/blood-2007-12130609

30. Carleton MM, Sefton MV. Injectable and degradable methacrylic acid hydrogel alters macrophage response in skeletal muscle. Biomaterials. (2019) 223:119477. doi: 10.1016/j.biomaterials.2019.119477

31. Sanui T, Fukuda T, Yamamichi K, Toyoda K, Tanaka U, Yotsumoto K, et al. Microarray analysis of the effects of amelogenin on U937 monocytic cells. Am J Mol Biol. (2017) 7:107-22. doi: 10.4236/ajmb.2017.72009

32. Fukuda $\mathrm{T}$, Sanui $\mathrm{T}$, Toyoda $\mathrm{K}$, Tanaka U, Taketomi $\mathrm{T}$, Uchiumi $\mathrm{T}$, et al. Identification of novel amelogenin-binding proteins by proteomics analysis. PLoS ONE. (2013) 8:e78129. doi: 10.1371/journal.pone.0078129

33. Jenuwein T, Allis CD. Translating the histone code. Science. (2001) 293:107480. doi: 10.1126/science. 1063127 
34. Beresford GW, Boss JM. CIITA coordinates multiple histone acetylation modifications at the HLA-DR promoter. Nat immunol. (2001) 2:6527. doi: $10.1038 / 89810$

35. Snowden AW, Gregory PD, Case CC, Pabo CO. Gene-specific targeting of $\mathrm{H} 3 \mathrm{~K} 9$ methylation is sufficient for initiating repression in vivo. Curr Biol. (2002) 12:2159-66. doi: 10.1016/S0960-9822(02)01391-X

36. Boyd NH, Morgan JE, Greer SF. Polycomb recruitment at the Class II transactivator gene. Mol Immunol. (2015) 67(2 Pt B):482-91. doi: 10.1016/j.molimm.2015.08.003

37. Dalton DK, Pitts-Meek S, Keshav S, Figari IS, Bradley A, Stewart TA. Multiple defects of immune cell function in mice with disrupted interferon-gamma genes. Science. (1993) 259:1739-42. doi: 10.1126/science.8456300

38. Gordon S. Alternative activation of macrophages. Nat Rev Immunol. (2003) 3:23-35. doi: 10.1038/nri978

39. Mosser DM, Edwards JP. Exploring the full spectrum of macrophage activation. Nat Rev Immunol. (2008) 8:958-69. doi: 10.1038/nri2448

40. Mantovani A, Sica A, Sozzani S, Allavena P, ecchi A, Locati M. The chemokine system in diverse forms of macrophage activation and polarization. Trends Immunol. (2004) 25:677-86. doi: 10.1016/j.it.2004.09.015

41. Montaner LJ, Silva RP, Sun J, Sutterwala S, Hollinshead M, Vaux D, et al. Type 1 and type 2 cytokine regulation of macrophage endocytosis: differential activation by IL-4/IL-13 as opposed to IFN-gamma or IL-10. J Immunol. (1999) 162:4606-13.

42. Nelms K, Keegan AD, Zamorano J, Ryan JJ, Paul WE. The IL-4 receptor: signaling mechanisms and biologic functions. Annu Rev Immunol. (1999) 17:701-38. doi: 10.1146/annurev.immunol.17.1.701

43. Mantovani A, Allavena P, Sica A. Tumour-associated macrophages as a prototypic type II polarised phagocyte population: role in tumour progression. Eur J Cancer. (2004) 40:1660-7. doi: 10.1016/S0959-8049(04)00285-0

44. Stout RD, Suttles J. Functional plasticity of macrophages: reversible adaptation to changing microenvironments. J Leukoc Biol. (2004) 76:50913. doi: $10.1189 /$ jlb. 0504272

45. Yamamichi K, Fukuda T, Sanui T, Toyoda K, Tanaka U, Nakao $\mathrm{Y}$, et al. Amelogenin induces M2 macrophage polarisation via PGE2/cAMP signalling pathway. Arch Oral Biol. (2017) 83:241-51. doi: 10.1016/j.archoralbio.2017.08.005

46. Hoang AM, Klebe RJ, Steffensen B, Ryu OH, Simmer JP, Cochran DL. Amelogenin is a cell adhesion protein. J Dent Res. (2002) 81:497500. doi: 10.1177/154405910208100713

47. Matsuzawa M, Sheu TJ, Lee YJ, Chen M, Li TF, Huang CT, et al. Putative signaling action of amelogenin utilizes the Wnt/beta-catenin pathway. $J$ Periodontal Res. (2009) 44:289-296. doi: 10.1111/j.1600-0765.2008.01091.x

48. Swanson EC, Fong HK, Foster BL, Paine ML, Gibson CW, Snead ML, et al. Amelogenins regulate expression of genes associated with cementoblasts in vitro. Eur J Oral Sci. (2006) 1:239-43. doi: 10.1111/j.1600-0722.2006.00321.x

49. Iacob S, Veis A. Identification of the functional activity of the [A-4] amelogenin gene splice product in newborn mouse ameloblasts. Bone. (2008) 42:1072-9. doi: 10.1016/j.bone.2008.01.023

50. Bartlett JD, Ganss B, Goldberg M, Moradian-Oldak J, Paine ML, Snead ML, et al. Protein-protein interactions of the developing enamel matrix. Curr Top Dev Biol. (2006) 74:57-115. doi: 10.1016/S0070-2153(06)74003-0

51. Tompkins K, George A, Veis A. Characterization of a mouse amelogenin [A-4]/M59 cell surface receptor. Bone. (2006) 38:172-80. doi: 10.1016/j.bone.2005.08.013
52. Wang H, Tannukit S, Zhu D, Snead ML, Paine ML. Enamel matrix protein interactions. J Bone Miner Res. (2005) 20:1032-40. doi: 10.1359/JBMR. 050111

53. Wang HJ, Tannukit S, Wen X, Shapiro JL, Snead ML, Paine ML. Using the yeast two-hybrid assay to discover protein partners for the leucine-rich amelogenin peptide and for tuftelin-interacting protein 11. Eur J Oral Sci. (2006) 114:276-9. doi: 10.1111/j.1600-0722.2006. 00289.x

54. Zhang H, Tompkins $\mathrm{K}$, Garrigues J, Snead ML, Gibson CW, Somerman MJ. Full length amelogenin binds to cell surface LAMP 1 on tooth root/periodontium associated cells. Arch Oral Biol. (2010) 55:417-25. doi: 10.1016/j.archoralbio.2010.03.009

55. Zou Y, Wang H, Shapiro JL, Okamoto CT, Brookes SJ, Lyngstadaas $\mathrm{SP}$, et al. Determination of protein regions responsible for interactions of amelogenin with CD63 and LAMP1. Biochem J. (2007) 408:34754. doi: 10.1042/BJ20070881

56. Martins L, Leme AF, Kantovitz KR, de Luciane Martins EN, Sallum EA, Casati MZ, et al. Leucine-Rich Amelogenin Peptide (LRAP) uptake by cementoblast requires flotillin-1 mediated endocytosis. J Cell Physiol. (2017) 232:55665. doi: $10.1002 /$ jcp. 25453

57. Toyoda K, Fukuda T, Sanui T, Tanaka U, Yamamichi K, Atomura R, et al. Grp78 is critical for amelogenin-induced cell migration in a multipotent clonal human periodontal ligament cell line. J Cell Physiol. (2016) 231:41427. doi: $10.1002 /$ jcp. 25087

58. Yang $\mathrm{M}$, Zhang $\mathrm{F}$, Qin $\mathrm{K}$, Wu $\mathrm{M}$, Li $\mathrm{H}$, Zhu $\mathrm{H}$, et al. Glucoseregulated protein 78 -induced myeloid antigen presenting cells maintained tolerogenic signature upon LPS stimulation. Front immunol. (2016) 7:552. doi: 10.3389/fimmu.2016.00552

59. Hatakeyama J, Philp D, Hatakeyama Y, Haruyama N, Shum L, Aragon $\mathrm{MA}$, et al. Amelogenin-mediated regulation of osteoclastogenesis, and periodontal cell proliferation and migration. J Dent Res. (2006) 85:1449. doi: 10.1177/154405910608500206

60. Ravindranath RM, Devarajan A, Bringas P Jr. Enamel formation in vitro in mouse molar explants exposed to amelogenin polypeptides ATMP and LRAP on enamel development. Arch Oral Biol. (2007) 52:1161-71. doi: 10.1016/j.archoralbio.2007. 06.008

61. Romanelli M, Dini V, Vowden P, Agren MS. Amelogenin, an extracellular matrix protein, in the treatment of venous leg ulcers and other hard-toheal wounds: experimental and clinical evidence. Clin Interv Aging. (2008) 3:263-72. doi: 10.2147/CIA.S1846

Conflict of Interest: The authors declare that the research was conducted in the absence of any commercial or financial relationships that could be construed as a potential conflict of interest.

Copyright (C) 2020 Yotsumoto, Sanui, Tanaka, Yamato, Alshargabi, Shinjo, Nakao, Watanabe, Hayashi, Taketomi, Fukuda and Nishimura. This is an open-access article distributed under the terms of the Creative Commons Attribution License (CC BY). The use, distribution or reproduction in other forums is permitted, provided the original author(s) and the copyright owner(s) are credited and that the original publication in this journal is cited, in accordance with accepted academic practice. No use, distribution or reproduction is permitted which does not comply with these terms. 